\begin{tabular}{|c|c|c|} 
INTERNATIONAL JOURNAL OF \\
ORGANANIZATIONAL \\
IEADESHHIP
\end{tabular}

\title{
Value-based Leadership Across Teachers' Ranks and Its Significance in Schools: A Case of Primary Schools in Kajiado North, Kenya
}

\author{
Joseph K. Sambu ${ }^{*}$, David Minja ${ }^{2}$, Jane A. Chiroma ${ }^{3}$ \\ 1, 3 PAC University, Nairobi, Kenya \\ ${ }^{2}$ Kenyatta University, Nairobi, Kenya
}

\section{Keywords: \\ Value-based Leadership, \\ Teachers, Head teacher, \\ Consistency, Values}

Received

11 May 2021

Received in revised form

27 May 2021

Accepted

10 June 2021

*Correspondence:

sambujoseph7@gmail.com

\begin{abstract}
This research assessed the practice of value-based leadership (VBL) of two ranks of primary school teachers in Kajiado North, Kenya. The study incorporated an explanatory sequential mixed-methods approach that utilized a pragmatic paradigm epistemology. Survey questionnaires were used to collect data from the teachers in the first quantitative phase and analyzed using (SPSS), v.25. In the second phase, interviews were conducted to gather qualitative information, which was thematically analyzed using Miner Lite software. The results from the quantitative phase showed a positive and significant relationship between the teachers' VBL and the head teachers' VBL. The practice of VBL in the two ranks of teachers was found to be consistent in integrity, trust, listening, respect, and inclusion and was inconsistent in vision and clear thinking. In the second phase, teachers described VBL as; leading through values and qualities, leadership that you see, leading by example, helping people grow and adding value to what they do, and doing what you are supposed to do by observing professional ethics. Consistency in the practice of VBL is critical in schools because it creates a uniform space where effective learning of values takes place. The study recommends the training of head teachers in VBL traits, in particular communication skills that will help them in delivering on vision and clear thinking. A replica of the study in the secondary school level is recommended to validate the findings.
\end{abstract}

CCIKD Publishing

Value-based leadership is a subject that has been gaining popularity in recent research. The motivation behind value-based leadership is attributed to the increasing societal challenges, such as intolerance, violent extremism, terrorism, and corruption that people have been encountering (Nyaga, 2018). While good research on value-based leadership has been done in 
the business industry (Copeland, 2014), studies are required in the education sector, where limited research on value-based leadership has been identified (Wamahiu, 2015).

Bullying, substance abuse, and examination dishonesty are some of the school challenges that may occur when leaders fail to cultivate values in students. For example, Examination dishonesty has been described as a school challenge that occurs when students lack values such as integrity (Anzene, 2014). Examination dishonesty has affected education systems across the levels (Akaranga \& Ongong'a, 2013) and has increased in recent years both in global, regional, and national examinations (Anzene, 2014). Cases of cheating in examinations, especially in national examinations, have been reported in Kenya severally (Akaranga \& Ongong'a, 2013; Amadala \& Kaluoch, 2015; Munuhe, 2016). This challenge requires a leadership solution.

Although literature identifies leadership as second to instruction in influencing school outcomes (Mitgang, 2012), its approach that emphasizes control systems to solve educational challenges tends to offer temporary solutions. For instance, cases of examination dishonesty, especially at the Kenya Certificate of Secondary Examinations (KCSE), are still being reported in the media despite deploying heavy security and control systems to manage the process (Situma \& Wasike, 2020). However, the researchers perceive value-based leadership as a strategy that offers a long-lasting solution to school challenges because the values cultivated by teachers in students will not only guide students to make the right decisions during examinations but help them live ethical lives after school.

Value-Based Leadership (VBL) is leadership that leaders exhibit through values. It refers to leadership based on foundational moral principles, ethics and, values such as integrity, empowerment, and social responsibility (Reilly \& Ehlinger, 2007, p. 246). Value-based leadership holds a few uncommon guarantees that other forms of leadership do not. An example to illustrate this is self-overseeing personnel; a lesser requirement for supervision and control; more respect between individuals; expanded energy and commitment to the undertaking; a reputation of reliability, fairness, and honesty; trust and faithfulness; improved integrity and responsibility; and better decision-making, which add to the vision (O'Toole, 1995).

\section{Statement of the Research Problem}

Value-based leadership studies in primary schools are rare (Adams, 2005). However, few studies on leadership within the secondary school level highlight the values of the principal, teachers, and students are described in the next paragraphs. Van Niekerk and Botha (2017) conducted qualitative research that assumed that school principals as leaders need to establish, develop, and maintain a core of shared values in their schools. The focus of the research was on principals' perceptions of values in their schools. Van Niekerk and Botha argue that the personal values of school principals underpin their decisions and actions and thus influence the members of the school. Although the results of their research show that the principals had diverse perceptions of values and that their values influenced the school community members, the research did not establish the extent of such influence.

A study carried out by Gold et al. (2003) explored how ten outstanding school principals in different kinds of schools in England translated their educational values into management and leadership practices. The results of the study showed that values drove the principals' leadership. Further, the value-based leadership approach used by the school principals provided 
insights on how values and beliefs can be understood in both words and deeds. However, it was also unsettling how research is silent on how the principals' values relate to those teachers.

While the studies conducted by Van Niekerk and Botha (2017) and Gold et al. (2003) agree in principle that the personal values of the head teachers influence the core values shared by the members of the school community, they do not show the extent to which the principal's values influence the values shared by the teachers. Furthermore, there has been a lack of research on value-based leadership relationships between different ranks of teachers (Copeland, 2014). In addition, value-based leadership studies are required in the preschool context (Wamahiu, 2015). The preschool stage is "critical for developing the foundations for thinking, behaving, and emotional well-being” (Bakken, Brown, \& Downing, 2017, p. 255). Further, research shows that children at the preschool age "develop linguistic, cognitive, social, emotional, and regulatory skills that predict their later functioning in many domains" (Bakken et al., 2017, p.255).

The researchers find the consistency in the practice of value-based leadership across the teachers' ranks crucial because it creates uniformity in the cultivation of regulatory skills and other essential values such as; respect, honesty, love, and integrity, whose result is uniform development of ethical behavior in children. Therefore, this research assessed the practice of value-based leadership among primary school teachers at different ranks in Kajiado North.

\section{Justification of the Study}

While some research on value-based leadership has been done in the business industry (Copeland, 2014), there is little research on value-based leadership in primary schools (Adams, 2005), and especially at the preschool level (Wamahiu, 2015). The research on the emerging significance of value-based leadership by Copeland (2014, p. 130) shows there is a lack of "VBL relationships at different professional ranks within an organization," which she says "when investigated will provide useful information." Consistent practice of values across teachers' ranks creates an efficient environment for learning. Research shows that students in classrooms where teachers' values are aligned show no differences in behavior, while those in learning environments where there's inconsistency within the practice of values are different in behavior (Gage, Scott, Hirn, \& MacSuga-Gage, 2018). Consistent practice of value-based leadership by teachers creates an ideal environment where moral values and regulatory skills are taught to shape students into responsible citizens. This study assesses the practice of valuebased leadership (VBL) and examines the relationship between the VBL of head teachers and the VBL of preschool teachers in Kajiado North. The following Research Question (RQ) and Hypothesis $(\mathrm{H})$ is addressed in the present study:

RQ: What is the relationship between the VBL of the head teachers and preschool teachers in Kajiado North?

Ho1: There is no relationship between the VBL of the head teachers and preschool teachers in Kajiado North. 


\section{Review of Related Literature Value-based Leadership}

Value-based leadership is defined as "goal-setting, problem-solving, language-creating, and value-developing interaction, which is anchored in the organization's values and high ethical standards" (Busch \& Murdock, 2014, p. 87). This definition connects with what happens in schools. For instance, teachers set goals for students to achieve and choose what to teach and how to teach. Head teachers and teachers need to practice value-based leadership consistently because they are role models that students emulate to achieve moral values such as love, respect, and honesty.

The implication of this is that children's characters are highly dependent on the values that teachers practice in school because values are observable and imitable. Some of the values drawn from the concept of value-based leadership that connects to children's learning include integrity, respect, listening, trust, clear thinking, vision, and inclusion. These values are indicators of value-based leadership (O'Toole, 1995), which can be measured according to Garg and Krishnan (2003). Figure 1 depicts the indicators (traits) of value-based leadership that teachers may use to guide students, instill moral values, and shape them into responsible citizens.

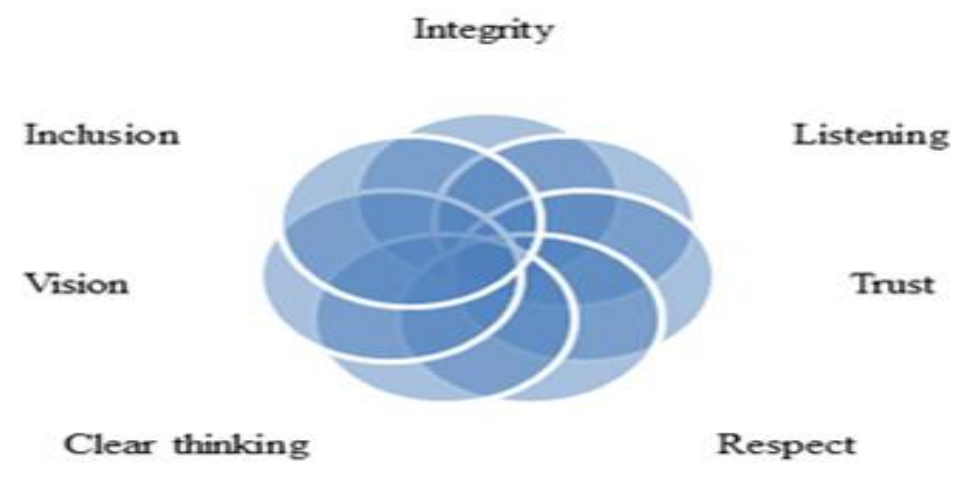

Figure 1. The concept of value-based leadership

Note. Adapted from O'Toole (1995), Smith (2014), and Sambu (2020, p. 37).

Table 1 describes how head teachers have used values to lead schools and guide teachers and students.

Table 1

The Indicators of a Value-Based Head Teacher

\begin{tabular}{lll}
\hline \multicolumn{2}{c}{ Characteristic } & \multicolumn{1}{c}{ Description of the headteacher } \\
\hline 1. & Integrity & $\begin{array}{l}\text { Integrity }- \text { is identical to truth-telling, honesty, high moral standards. A headteacher whose } \\
\text { words and deeds are consistent knows themself well and never loses sight of their goals } \\
\text { nor compromises their principles }\end{array}$ \\
\hline 3. & Vision & Builds a vision and finds ways of communicating it to inspire teachers \\
\hline 4. & Listening & $\begin{array}{l}\text { Inspires trust and hope in teachers who, in turn, become encouraged to serve, to sacrifice, } \\
\text { to persevere, and to lead change. In turn, teachers become loyal to the school }\end{array}$ \\
\hline & $\begin{array}{l}\text { Listens to the teachers because they respect them and honestly believe that the welfare of } \\
\text { the teachers is the end of leadership. Encourages dissenting opinion among their closest } \\
\text { advisers and is not a slave to public opinion }\end{array}$ \\
\hline Respect & $\begin{array}{l}\text { Committed to the moral principles of respect for teachers. Head teachers who succeed at } \\
\text { bringing about practical and moral change believe in and act on the inherent dignity of the } \\
\text { teachers they lead }\end{array}$ \\
\hline
\end{tabular}




\begin{tabular}{ll}
\hline 6. Clear thinking & $\begin{array}{l}\text { Must have clear thoughts about their own beliefs, human nature, the role of the school, and } \\
\text { the measurement of performance. Listens to the needs, ideas, and aspirations of the } \\
\text { teachers, and then, within the context of their well-developed systems of belief, } \\
\text { responds to these in the appropriate fashion }\end{array}$ \\
\hline 7. Inclusion & $\begin{array}{l}\text { Inclusive head teachers enable teachers to lead by sharing information, fostering a sense of } \\
\text { community, and creating consistent rewards, structure, process, and communication } \\
\text { systems. They are committed to the principle of opportunity, giving all teachers the chance } \\
\text { to contribute to the school. }\end{array}$ \\
\hline
\end{tabular}

Note. Adapted from Garg and Krishnan (2003) and Sambu (2020, p. 39)

\section{Empirical Review}

In schools, quantitative studies relating to headteacher leadership and teacher results have been conducted. Liu, Bellibaş, and Gümüş (2021), for example, looked at the impacts of instructional leadership and distributed leadership on teacher job satisfaction and self-efficacy. The study found that distributed leadership and instructional leadership positively and directly associated with teacher job satisfaction and teacher self-efficacy, respectively.

Another quantitative study by Ahmad and Hamid (2020) looked at teachers' assessments of the impact of primary school head teachers' instructional leadership strategies on teacher effectiveness. The findings demonstrated that primary school head teachers' instructional leadership methods regarding school inputs, teacher effectiveness are significantly influenced by school procedures and outcomes. However, teacher gender and experience have a minor role in the relationship between instructional leadership practices and teacher effectiveness.

Liu and Wang (2020) carried out a research to understand the relationship between transformational leadership and collective teacher efficacy in the Chinese primary school context. The findings of the study revealed that when collective teacher efficacy is treated as a single variable, setting direction and managing the instructional program have relatively significant effects on collective teacher efficacy.

The literature reviewed revealed that head teachers' features of transformational, distributed, and instructional leadership positively impact teachers' work satisfaction, self-efficacy, and effectiveness, but they do not show how head teachers' VBL relates with preschool teachers' VBL. The findings of an in-depth investigation of the emerging significance of value-based leadership unmask a shortage of VBL relationships at various professional levels in organizations (Copeland, 2014, p. 129). According to Copeland (2014), examining VBL relationships across professional ranks can provide useful information. This study investigated the relationship between the VBL of head teachers and the VBL of preschool teachers in Kajiado North, Kenya.

\section{Theoretical Framework}

A theoretical framework is the application of a theory or a set of concepts drawn from one and the same theory to explain an event or shed some light on a phenomenon or research problem (Imenda, 2014). The social cognitive learning theory guided this research. At the center of social cognitive learning is observational learning, where teachers observe the behavior of their headteacher and learn values from it, as shown in Figure 2. The behavior of teachers is considered an influence in a learning environment where learners look up to the teacher (leader) for guidance and direction (Bandura, 1977). Under the social influences, the value-based leadership of teachers and head teachers was considered critical for the study since their 
behavior, as intervened by the social cognitive theory, can influence pupils' values, model their behavior, and make them responsible citizens (Bandura, 2018).

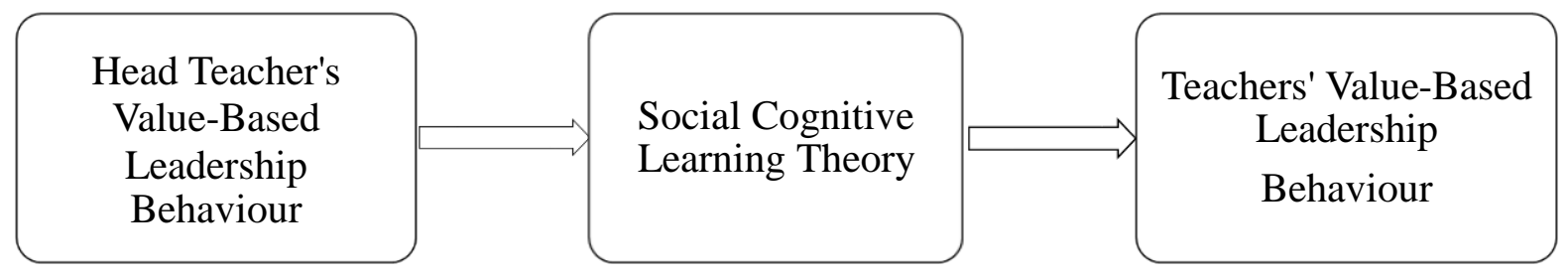

Figure 2. Theoretical framework for the research.

Note: Compiled from research data

\section{Conceptual Framework}

A conceptual framework is a group of related concepts that explain or predict a given event or provide a broader understanding of the phenomenon of interest or research problem (Imenda, 2014). In other words, a conceptual framework shows how the research variables relate to each other. The conceptual framework for this research (Figure 3) demonstrates how the VBL of head teachers $\left(\mathrm{X}_{1}\right)$ relate to the VBL of teachers $\left(\mathrm{X}_{2}\right)$. Value-based leadership has seven indicators: integrity, vision, trust, listening, respect, clear thinking, and inclusion. As the primary school leader in which the preschool is situated, the headteacher is required to offer $\operatorname{VBL}\left(\mathrm{X}_{1}\right)$, which is assumed to influence the teachers' $\operatorname{VBL}\left(\mathrm{X}_{2}\right)$.

Social Cognitive Theory suggests that teachers' behavior is primarily learned by observing peers and the behavior of the headteacher and interactions with the learning environment (Bandura, 1997). To find the extent to which value-based leadership of the headteacher influences teachers' value-based leadership, all other factors that moderate the learning outcomes according to Bandura's cognitive learning theory were held constant. It was assumed that teachers only observe the behavior of the headteacher and absorb the values (see Figure 3 ).

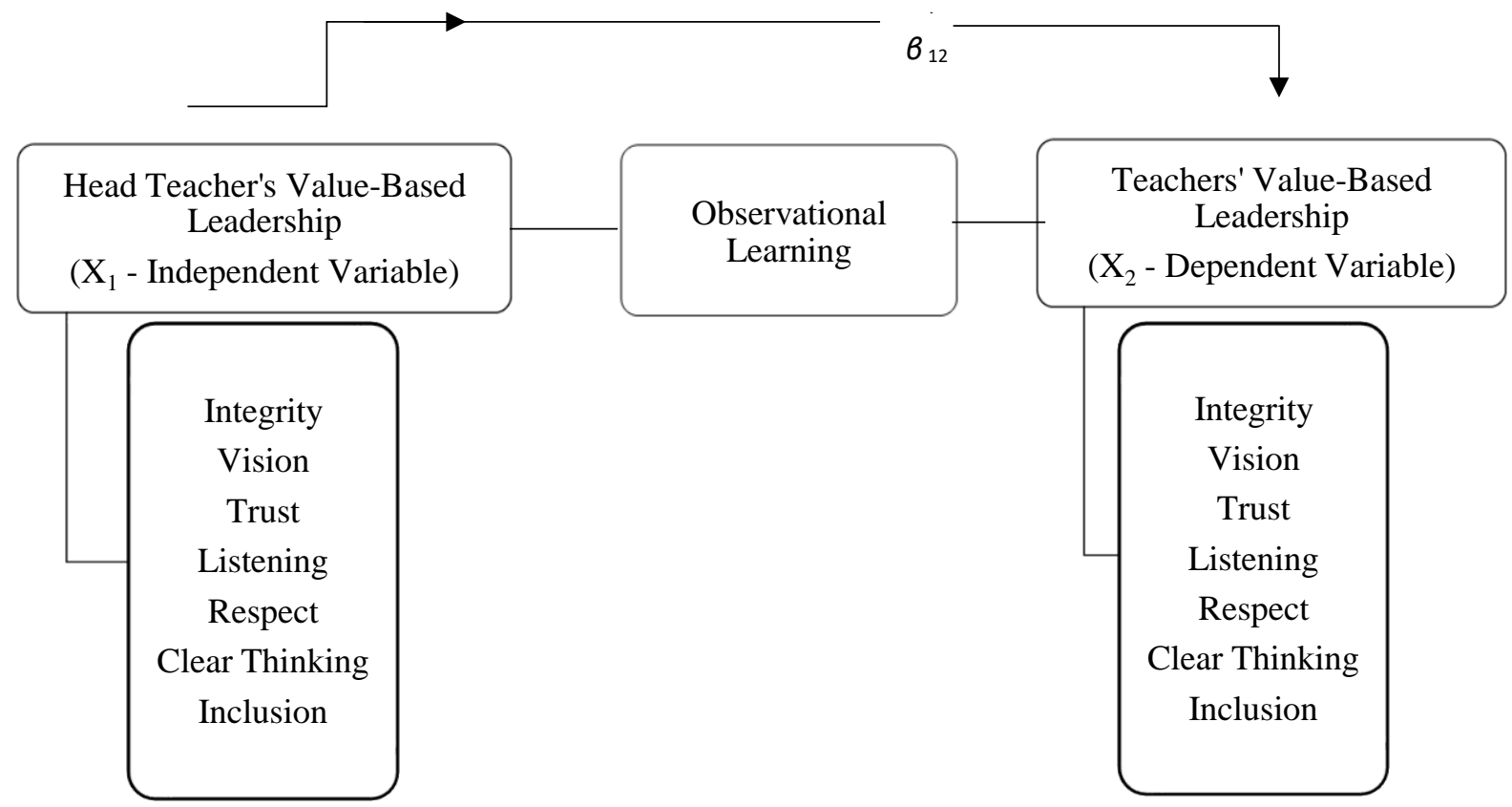

Figure 3. Conceptual framework for the research

Note: Compiled from research data 


\section{Methodology}

This study incorporated a mixed-methods approach that utilized a pragmatic paradigm (Creswell \& Plano Clark, 2011). From a pragmatic worldview, research focuses more on the research question and how to find the answers than on the theory behind how knowledge is created (Creswell, 2014). This research sought to answer the question, "What is the relationship between the VBL of the head teachers and the VBL of the preschool teachers in Kajiado North?" Interviews were conducted with selected respondents with a follow-up question that asked the head teachers and preschool teachers to describe the meaning of VBL in their own words. Table 2 shows how the pragmatic framework was operationalized in the research.

Table 2

Framework for the Pragmatic Application of this Research

\begin{tabular}{|c|c|c|c|}
\hline Objective & Hypothesis & $\begin{array}{l}\text { Research questions } \\
\text { Quantitative }\end{array}$ & $\begin{array}{l}\text { Qualitative } \\
\text { (follow-up) }\end{array}$ \\
\hline $\begin{array}{l}\text { To examine the relationship } \\
\text { between the VBL of head } \\
\text { teachers and the VBL of } \\
\text { preschool teachers in Kajiado } \\
\text { North. }\end{array}$ & $\begin{array}{l}\mathrm{H}_{0} 1 \text { : There is no significant } \\
\text { relationship between the VBL of } \\
\text { head teachers and preschool } \\
\text { teachers in Kajiado North. }\end{array}$ & $\begin{array}{l}\text { What is the relationship between } \\
\text { the VBL of the head teachers and } \\
\text { the VBL of the preschool teachers } \\
\text { in Kajiado North? }\end{array}$ & $\begin{array}{l}\text { What does VBL mean to the } \\
\text { head teachers and preschool } \\
\text { teachers in Kajiado North? }\end{array}$ \\
\hline
\end{tabular}

\section{The Study Population and Sample Size}

At the time of this study, only 150 primary schools in Kajiado North had preschool units in the same compound. The total population of this study was taken as 300. This allowed a headteacher to be paired with a preschool teacher and taken as a case in the study. The pairing permitted the researchers to establish the relationship between the headteacher's VBL and that of the preschool teachers and enabled the consistency in the practice of VBL in the two ranks of teachers (teacher, headteacher) to be tested. The sample population of the research was 50 primary schools, statistically selected after considering some factors. Although time and financial constraints limited the number of schools that were included in the survey, the 50 schools chosen as the study's target population met the criteria for a margin of error of 5\% at $95 \%$ level of confidence (Kothari \& Garg, 2014). The computation that gave 50 schools as the sample was done as explained in the following paragraph. The sample size for the target population was computed using the formula:

$n=\frac{z^{2} \cdot p \cdot q \cdot N}{e^{2}(N-1)+z^{2} \cdot p \cdot q} \quad$ where

$n=$ sample size

$\mathrm{z}=$ standard score,

$$
p=\text { confidence level, }
$$

$q=1-p$,

$e=$ acceptable error, and $\mathrm{N}=$ size of the population (Kothari, 2004, p. 179).

This computation gave the sample size (n) for the target population in the distribution (see Table 3).

Table 3

Distribution of Respondents in the Population

\begin{tabular}{lccc}
\hline Category of respondents & Size of population $(\mathrm{N})$ & Calculated $(\mathrm{n})$ & \\
\hline Head teachers & 150 & 49.3 & Target $(\mathrm{n})$ \\
Preschool teachers & 150 & 49.3 & 50 \\
Total & 300 & 98.6 & 50 \\
\hline
\end{tabular}

Note. Research Data (Sambu, 2020, p. 78) 


\section{Sampling Procedures}

In the first phase, the simple stratified sampling technique was used to form two equal subpopulations, namely (1) head teachers and (2) preschool teachers. The population is divided into several subpopulations in stratified sampling that are individually more homogeneous than the total population (Kothari, 2004, p. 62). The 50 schools were chosen from the five regulatory wards, namely Ngong, Olkeri, Oloolua, Ongata Rongai, and Ngaimurunya (IEBC, 2017). The synopsis of private and public schools from which the quantitative information was gathered is shown in Table 4.

Table 4

The Distribution of Respondents in the Strata

\begin{tabular}{lccc}
\hline Type of school & Target population & Calculated strata & Sample size (n) \\
\hline Private & 136 & 45.3 & 45 \\
Public & 14 & 4.6 & 5 \\
Total & 150 & 49.9 & 50 \\
\hline Source.
\end{tabular}

Source. Research Data (Sambu, 2020, p. 80)

In the second phase, eight interviewees were purposively selected from head teachers and preschool teachers in public and private schools. Intentional selection is utilized when a different view is fundamental or if the perspective of specialists in a specific field is the point of inquiry (Bryman, 2012).

In this research, the perspectives of head teachers and preschool teachers on the concept of VBL were required to explain the relationship between the VBL behavior of the two ranks of teachers. The participants' selection was based on factors such as gender, the type of school private or public, rural or urban, and sponsored by an interested group or not. Many school attributes were included in the sample because samples without representativeness may not be dependable sources to draw inferences about the population (Bryman, 2012). The participants for the interview phase were selected, as shown in Table 5 .

Table 5

The Demographics of Respondents in the Qualitative Phase

\begin{tabular}{cccc}
\hline Respondent & Age & Gender & School category \\
\hline $\mathrm{T}_{1}$ & $30-39$ & $\mathrm{~F}$ & Private \\
$\mathrm{HT}_{1}$ & Above 50 & $\mathrm{~F}$ & Private \\
& & & $\mathrm{F}$ \\
$\mathrm{T}_{2}$ & $40-49$ & $\mathrm{M}$ & Public \\
$\mathrm{HT}_{2}$ & $40-49$ & $\mathrm{~F}$ & Private \\
$\mathrm{T}_{3}$ & Below 30 & $\mathrm{~F}$ & \\
$\mathrm{HT}_{3}$ & Above 50 & $\mathrm{~F}$ & $\mathrm{~F}$ \\
$\mathrm{~T}_{4}$ & $40-49$ & $40-49$ &
\end{tabular}

Source. Research Data (Sambu, 2020, p. 132)

\section{Collection of Data}

In the first phase, the study used questionnaires to collect quantitative data because they are less expensive than other methods. Questionnaires also generate massive data within a short time; they are free of bias from the questioner since the answers are given in the interviewees' own words, and interviewees have enough time to make very considered replies, and questionnaires are a means of conveniently reaching respondents who are not easily approachable (Kothari, 2004). In the second phase, data were gathered using qualitative 
techniques. The motivation behind qualitative research is to enable researchers to comprehend or clarify human conduct and convictions and get a proper explanation of questions (Hennink, Hutter, \& Bailey, 2011). In addition, qualitative information helps explain the initial quantitative results (Creswell, 2014). Qualitative information was gathered via face-to-face interviews with purposely selected head teachers and preschool teachers. The purposeful selection was guided by the inquiries that needed clarification and a better understanding, as observed in phase one of this study. For instance, outliers observed in the survey gave a clue to issues in the schools where the questionnaires were completed. Therefore, teachers from some schools where the outliers were observed were taken as participants in the interviews. The researchers selected the participants hoping to use their perspectives and experiences to understand the unexpected outcomes, as indicated by the extreme values in the questionnaires.

\section{Instruments}

For the quantitative part, a survey aided by a value-based leadership questionnaire developed by Garg and Krishnan (2003) was used to measure the VBL of the teachers and head teachers. The VBL questionnaires have 20 items capturing all the constructs of authenticity, ethics, morality, and service. A participant was required to respond to the characteristics of leadership exhibited by the headteacher (teacher's questionnaire) and those exhibited by the teacher (headteacher's questionnaire). Participants were required to check $(\sqrt{ })$ the most appropriate response according to a five-point Likert scale, with $1=$ Never, $2=$ Rarely, $3=$ Sometimes, 4 $=$ Most of the time, and $5=$ All the time.

\section{Reliability of the VBL Questionnaires}

Internal consistency refers to the level of consistency or exactness with which an instrument measures the trait it has been intended to gauge (Polit \& Hungler, 2013). SPSS generates the reliability measure of the questionnaire, called the Cronbach's alpha $(\alpha)$, where $\alpha \geq .7$ is considered a good measure of reliability (Kothari \& Garg, 2014). In addition, Keith (2014) affirms that a good instrument should produce consistent results when used over time or when used in various locations in the same context.

The questions included in the questionnaires estimated the levels of the constructs associated with value-based leadership. Although the VBL questionnaire had been tested in previous research (Garg \& Krishnan, 2003), testing of its reliability again was prudent because this research was carried out in the primary school context. According to Converse and Presser (1986), pretesting the questionnaires is a way of checking if the questionnaires are working properly. The questionnaires were pretested with a pilot study group that incorporated eight primary schools, giving $16 \%$ of the targeted population of fifty (50) schools. The recommended percentage for a sample size that should be engaged in a pilot test is $10 \%$ to $20 \%$ of the target population (Simon, 2011); hence the eight schools met the requirement. The headteacher and one of the preschool teachers in each of the eight schools were requested to complete the questionnaires. All 16 participants completed the questionnaires and returned them to the researchers. The questionnaires were analyzed to check the internal consistency of each question (item) using SPSS 25. The outputs from the analysis were studied and, for each head teachers' VBL questionnaire, the average value of Cronbach's alpha $(\alpha)$ based on the 20 items reached .83 while that of the teachers' VBL questionnaire was .88 . 


\section{Validity of the VBL Questionnaires}

Validity is connected to the precision of the data obtained in the gathering stage or given out as a report after the investigation. Validity is considered as the degree to which an instrument estimates what is normal and what it professes to gauge (Punch, 2014). For the instrument to be considered valid, it should measure all variables represented in the conceptual framework (content validity), and the measures should conform to the ideals described in the theoretical framework (construct validity), as explained by Bryman and Bell (2015). The questions used in the VBL questionnaires were described in the literature review and explained in the section on the theoretical and conceptual frameworks. The information collected from the pilot study was applied in testing the content validity of the instruments.

Content validity is the degree to which an estimation instrument adequately includes the theme under examination (Kothari \& Garg, 2014). Assurance of content validity should be possible by a board of people who pass judgment on how well the estimation instrument satisfies the guidelines since there is no numerical method to express it (Kothari \& Garg, 2014). The results from the pilot study showed the inclusion of all the indicators of Value-based leadership. The measurements from the questionnaires per indicator varied slightly from each another, indicating the instruments' potential to measure the constructs they were intended to measure (Creswell, 2014). After confirming the reliability and validity of the research instruments, the researchers went to the field to collect data from the 100 targeted respondents in the 50 primary schools.

\section{Validity and Reliability of The Teacher Interviews}

While it may be easy to determine the reliability of a quantitative research instrument using observable measures like Cronbach's alpha $(\alpha)$, where $\alpha>.7$ is considered a good measure of reliability (Kothari \& Garg, 2014), there are no such measures in qualitative research. Stenbacka (2001) does not believe there is such a thing as reliability in qualitative research. Instead of the term reliability, some authors have proposed the use of credibility, neutrality or confirmability, consistency or dependability, and applicability or transferability (Lincoln \& Guba, 1985). To accomplish these in qualitative research, a review of effects such as basic information, information reduction outcomes, and procedure notes ought to be done (Campbell, 1996). Furthermore, Patton (2001) views the researchers as the instrument; subsequently, the information gathered relies upon the researchers' effort and expertise. To ensure the trustworthiness and transferability of data (Seale, 1999), the researchers recorded the interviews after obtaining consent from the respondents to capture the information accurately. The participants' responses were triangulated with the findings of similar research that was carried out in the same context.

\section{Analysis and Interpretation of Data}

For the quantitative phase, the average scores of all indicators in each variable (described in the instruments section) were taken to indicate the levels of VBL. Microsoft Excel version 2019 was used to generate mean scores for all pointers of the variables indicated in the conceptual framework and produce tables and figures. The mean scores labeled as ordinal or ratio were transferred to the Statistical Package for Social Sciences (SPSS) for further analysis to obtain descriptive statistics such as mean $(M)$ and standard deviation $(S D)$. As presented in Table 6 , 
the mean scores were interpreted using the interpretation scale developed by Nunnally and Berstein (1994).

Table 6

Interpretation of VBL Levels

\begin{tabular}{ll}
\hline Mean score (M) & Interpretation \\
\hline 1.00 to 2.00 & Low \\
2.01 to 3.00 & Moderately low \\
3.01 to 4.00 & Moderately high \\
4.01 to 5.00 & High \\
\hline Source. Research Data (Sambu, 2020, p. 91$)$ & \\
\hline
\end{tabular}

Source. Research Data (Sambu, 2020, p. 91)

To test the consistency of VBL practice by the two ranks of teachers, a correlation coefficient ( $r$ ) was used. In correlation analysis, the correlation coefficient value $(r)$ shows the strength of the relationship between the dependent and the independent variable, while the sign of $r$ specified the direction of the relationship. The interpretation of $(r)$ was made using Cohen's (1988) scale (see Table 7).

Table 7

Interpretation of Correlation Coefficients

\begin{tabular}{ll}
\hline Correlation coefficient $(\mathbf{r})$ & Interpretation \\
\hline \pm 0.01 to \pm 0.29 & Low positive/Low negative \\
\pm 0.30 to \pm 0.49 & Moderate positive/Moderate negative \\
\pm 0.50 to \pm 1.00 & High positive/High negative \\
\hline
\end{tabular}

Source: Cohen (1988), Sambu (2020, p. 92)

The consistency of the practice of VBL in the two ranks of teachers was confirmed using Spearman's rho correlation coefficients, which utilized pairs $\left(\mathrm{X}_{1}, \mathrm{X}_{2}\right)$ of the seven indicators of VBL. Consistency in the practice of VBL was confirmed when a strong correlation $\left(r_{s}>.7\right)$ and a significant value $(p<.001)$ were obtained (Yue, Pilon, \& Cavadias, 2002). The two variables, $\mathrm{X}_{1}$ and $\mathrm{X}_{2}$, were confirmed to be consistent as they were found to be strongly correlated, $\mathrm{r}_{\mathrm{s}}(\mathrm{N}-$ $1)>.7, p<.001$, where N-1 is the degrees of freedom (Yue et al., 2002).

To find if the consistency in the practice of VBL was significant between the two ranks of teachers, the paired sample $t$-test was done. According to Maverick (2018), a paired sample ttest is used when two samples are involved, and the values for each sample are collected from the same individuals (that is, everyone gives two values, one for each of the two groups), or the samples come from matched pairs of individuals. In this research, the VBL of the teachers was matched with the VBL of the head teachers $\left(\mathrm{X}_{1}, \mathrm{X}_{2}\right)$. The paired-samples $t$-test was used to test hypothesis $\mathrm{H}_{0} 1$. The $t$-test was meant to determine if there was a difference in the mean scores of teachers' VBL and head teachers' VBL.

\section{Analysis of the Interviews}

After collecting views from the teachers on their understanding of value-based leadership, the researchers used thematic analysis techniques to put together the information given, broke it down into small bits that were easy to understand and interpret in line with the research question (Bogdan \& Biklen, 1982). The technique of breaking down qualitative data includes coding or ordering the information. Essentially, thematic analysis entails understanding enormous volumes of information by decreasing the volume of basic data, followed by distinguishing massive datasets, and lastly determining the importance of the information and, in this manner, 
assembling a coherent chain of evidence (Patton, 2015). A thematic examination is a technique for identifying, breaking down and describing designs (themes) from the data (Braun \& Clarke, 2006). Even though "[t]hematic analysis is widely used," there is no explicit agreement about "what thematic analysis is and how you go about doing it" (Braun \& Clarke, p. 6).

The qualitative data from the audio recordings were transcribed using Otter.ai (a free mobile application for smartphones). Initially, the researchers had planned to use NVivo for thematic analysis. This study used Miner Lite V2.0. 6, which is free software. The transcripts were edited to remove redundancies before transferring them to Miner lite. The use of software in analyzing qualitative data saves a great deal of time, which gives the researchers more time to investigate patterns, distinguish themes, and draw inferences (Patton, 2015).

Investigating personal information has become a lot simpler with the use of modern computer tools. The researchers applied Microsoft Office analysis tools v. 2019 to compile figures and tables that summarise the themes. Figures and tables help enhance the visualization of the relationships that this study sought to establish. The visualization of the relationships helped the researchers to link the two sets of data (quantitative and qualitative), which facilitated the discussions on the consistent practice of VBL across teacher ranks and its implication for schooling in Kenya.

\section{Results and Discussion}

\section{The Response Rate}

After confirming the reliability of the instruments, 100 questionnaires were administered to head teachers and preschool teachers in the 50 schools. All the questionnaires were returned, but they were scrutinized for completeness, and only 48 pairs were complete. A response rate of $50 \%$ is acceptable, $60 \%$ is good to analyze and publish, and $70 \%$ and above is outstanding (Babbie, 2004); hence the response rate of $96 \%$ met the requirement for the analysis.

\section{Results of the Assessment of Head Teachers VBL Questionnaires}

The mean scores of all the indicators per case (school) were entered into SPSS v.25 to produce descriptive statistics for the two variables: head teacher's VBL $\left(\mathrm{X}_{1}\right)$ and teacher's VBL $\left(\mathrm{X}_{2}\right)$. The average of the seven mean scores was taken as the level of VBL (Table 8). The levels of VBL were interpreted as shown in Table 8.

Table 8

The Level of the Head Teachers' VBL

\begin{tabular}{|c|c|c|c|c|c|}
\hline & $\mathrm{N}$ & Minimum & Maximum & $M$ & $S D$ \\
\hline HTI & 48 & 3.0 & 4.5 & 3.70 & .40 \\
\hline HTV & 48 & 3.5 & 4.5 & 3.91 & .44 \\
\hline HTT & 48 & 3.3 & 5.0 & 4.57 & .59 \\
\hline HTL & 48 & 3.5 & 5.0 & 4.18 & .51 \\
\hline HTR & 48 & 3.7 & 5.0 & 4.34 & .45 \\
\hline HTCT & 48 & 3.5 & 5.0 & 4.27 & .65 \\
\hline HTIN & 48 & 3.3 & 5.0 & 4.39 & .56 \\
\hline Head teacher's VBL $\left(\mathrm{X}_{1}\right)$ & 48 & 3.6 & 4.5 & 4.19 & .33 \\
\hline Valid N (listwise) & 48 & & & & \\
\hline
\end{tabular}

Source. Research Data (Sambu, 2020, p.111)

Note. The indicators of the head teachers' value-based leadership are abbreviated as: HTI-Head Teachers' Integrity, HTV-Head Teachers' Vision, HTT-Head Teachers' Trust, HTL-Head Teachers' Listening, HTR-Head Teachers' Respect, HTCT-Head Teachers' Clear Thinking, and HTIN-Head Teachers' Inclusion. 
Preschool teachers rated the head teachers' trust the highest, at $4.57(S D=.59)$, meaning they trusted their head teachers all the time in school. The high rating of $4.57(S D=.59)$ for trust is an indication that the head teachers involved preschool teachers in decision-making on matters of the curriculum and supported them, especially in the implementation of citizenship education.

At the lower end of the ratings are the head teachers' integrity and vision, at $3.70(S D=.40)$ and $3.91(S D=.44)$, respectively. These results indicate that the preschool teachers perceived their head teachers as truthful, honest, and of good moral behavior most of the time - meaning there were cases when they failed to live by these principles. In terms of vision, the teachers perceived their heads as having an inspiring vision, which they found ways to communicate to both the teachers and pupils most of the time. Inclusion and listening received ratings of 4.39 $(S D=.56)$ and $4.18(S D=.51)$ respectively.

The head teachers' overall level of VBL practiced as perceived by the preschool teachers was $4.19(S D=.33)$, meaning the head teachers practiced value-based leadership most of the time, as indicated on the scale of the tool used in the study. This finding is similar to that of Van Niekerk and Botha (2017) in their research paper on VBL. They found that nine school head teachers said they practiced VBL most of the time through values such as "[i]nclusivity, integrity, equity, loyalty, consistency, trust, Ubuntu, Christianity, cooperation, professionalism, accountability, kindness and democracy" (Van Niekerk \& Botha, 2017, p. 138).

\section{Results of the Assessment of Teachers VBL Questionnaires}

The mean scores of all the indicators per case (school) were entered into SPSS 25 to produce descriptive statistics for teacher's VBL $\left(\mathrm{X}_{2}\right)$. Table 9 shows the level of the teachers' VBL as perceived by the 48 head teachers. The levels of VBL were interpreted as shown in Table 9.

Table 9

The Level of the Teachers' VBL

\begin{tabular}{lccccc}
\hline & $\mathrm{N}$ & Minimum & Maximum & $M$ & \multicolumn{1}{c}{$S D$} \\
\hline TI & 48 & 3.0 & 5.0 & 4.17 & 4.18 \\
TV & 48 & 3.5 & 5.0 & 4.48 & .68 \\
TT & 48 & 2.7 & 5.0 & 3.96 & .79 \\
TL & 48 & 2.0 & 5.0 & 4.01 & .11 \\
TR & 48 & 2.0 & 5.0 & 3.96 & .83 \\
TCT & 48 & 2.5 & 5.0 & 3.87 & .66 \\
TIN & 48 & 3.0 & 5.0 & 4.07 & .66 \\
\hline Teacher's VBL $\left(\mathrm{X}_{2}\right)$ & 48 & 3.1 & 5.0 & & \\
\hline
\end{tabular}

Source. Research Data (Sambu, 2020, p.112)

Note. The indicators of the teachers' value-based leadership are abbreviated as: TI-Teachers' Integrity, TV-Teachers' Vision, TT-Teachers' Trust, TL-Teachers' Listening, TR-Teachers' Respect, TCT-Teachers' Clear Thinking, and TIN-Teachers' Inclusion.

The head teachers ranked the teachers' trust at $4.48(S D=.79)$. The vision and integrity of the teachers were ranked second and third, at $4.18(S D=.68)$ and $4.17(S D=.67)$, respectively. The high rating (according to the interpretation scale) indicates that preschool teachers were trusted most of the time because of their integrity, their willingness to serve, and the hope they stimulated in pupils, as reflected by the specific questions in the VBL tool. At the other end, inclusion, clear thinking, listening, and respect were perceived at moderately high levels, of $3.87(S D=.66), 3.96(S D=.88), 3.96(S D=1.11)$, and $4.01(S D=.93)$ respectively. These scores indicate that the teachers listened to the pupils, encouraged dissenting opinions among their closest advisers, shared information, and fostered a sense of community with the pupils. 
The overall rating of $4.07(S D=.66)$, interpreted as 'high' on the interpretation scale, showed that teachers practice VBL' most of the time' (as indicated by the rating scale used) at a lower level when compared to that of the head teachers. This result is consistent with that of Mansor et al. (2018). The purpose of their study was to identify the influence of ethical leadership practices in school principals on teachers' work engagement dimensions as perceived by teachers in two distinguished high-performing secondary schools in a district in Malaysia. The principals of both schools had moderately high to high ethical leadership practices, while teachers in both schools displayed moderately high to high work engagement. Mansor et al. (2018) inferred from the results that the principals of high-performing schools have traces of ethical leadership practices in their leadership style that promote teacher work engagement.

\section{Consistency in the Practice of VBL}

Even though the mean scores of $4.19(S D=.33)$ and $4.07(S D=.66)$ suggest that both head teachers and teachers respectively practiced VBL most of the time, as interpreted from the scale of the VBL tool used, how consistent was the practice in the two ranks? Were teachers practicing VBL at the same level as the head teachers in all seven indicators? To answer these questions, a statistical test for consistency was performed. The consistency was confirmed through Spearman's rho $\left(r_{\mathrm{s}}\right)$ correlation coefficients, which utilized pairs $\left(\mathrm{X}_{1}, \mathrm{X}_{2}\right)$ of the seven indicators of VBL with data coming from the 48 participants (see Table 10).

Table 10

The Spearman's Rho Correlation Coefficients for $\operatorname{VBL}\left(X_{1}, X_{2}\right)$

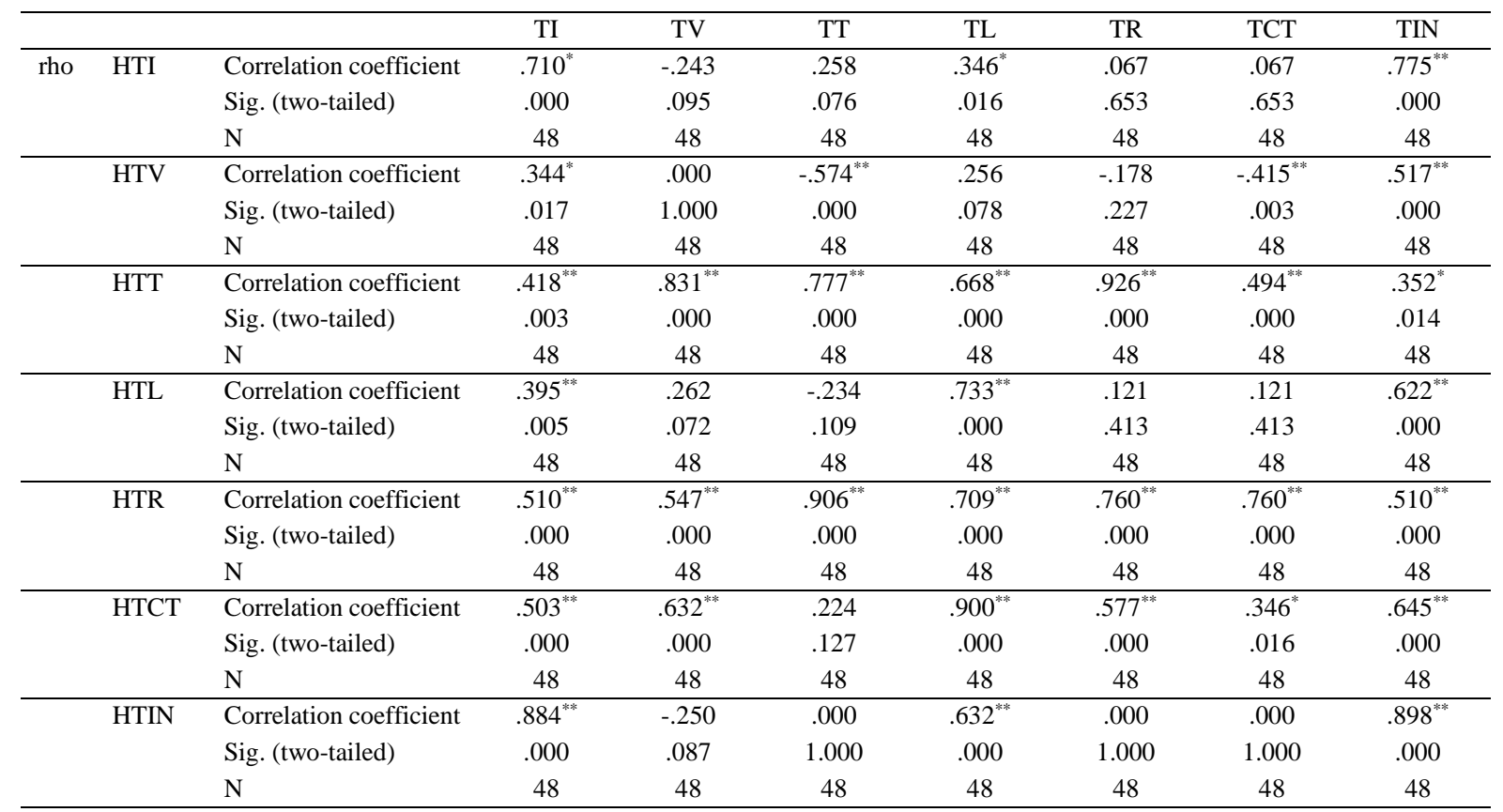

${ }^{* * *}$ Correlation is significant at the .05 level (two-tailed), ${ }^{*}$ Correlation is significant at the .05 level (two-tailed).

Source. Research Data (Sambu, 2020, p.115)

Consistency in the practice of VBL is confirmed when a strong correlation $\left(r_{s}>.7\right)$ and a significant value $(p<.001)$ are obtained (Yue et al., 2002). The Spearman's correlation coefficients from SPSS exhibited strong, positive correlations between $\mathrm{X}_{1}$ and $\mathrm{X}_{2}$, showing consistency in the practice of VBL through integrity $\left(r_{s}=.71, p<.001\right)$, trust $\left(r_{s}=.78, p<\right.$ $.001)$, listening $\left(r_{s}=.73, p<.001\right)$, respect $\left(r_{s}=.76, p<.001\right)$, and inclusion $\left(r_{\mathrm{s}}=.90, p<.001\right)$. 
The results are consistent with previous research findings, where strong, positive relationships between authentic leaders and authentic followers based on organisational outcomes were found (Avolio \& Gardner, 2005; Brown \& Treviño, 2006; Luthans \& Avolio, 2003; May et al., 2003).

There were inconsistencies in the practice of VBL in vision $\left(r_{s}=.000, p>.001\right)$ and clear thinking $\left(r_{s}=.35, p>.001\right)$. The inconsistencies in vision and clear thinking could stem from the head teachers' failure to communicate the vision to the teachers. Previous studies support this assertion by the researchers; for instance, Dean (2008) said that a value-based head teacher has to create a vision and inspire teachers to make that vision a reality. In addition, values-based head teachers create followers by enabling them to see clearly and achieve effectively, which they hold dear (O'Toole, 2008).

\section{The Relationship Between Head Teachers' VBL and Teachers' VBL}

The following research hypothesis was tested to find the relationship between the dependent and the independent variable as shown in the conceptual framework (see Figure 2).

$\mathrm{H}_{0} 1$ : There is no relationship between the teachers' VBL and the head teachers' VBL.

The decision to reject or accept the null hypothesis was made utilizing the sample paired $t$ test and simple regression analysis. Among the statistics displayed in the analysis, outputs are the path coefficients $\left(\beta_{12}\right)$, which show how two variables behave when all other factors are held constant, the correlation coefficient (r), which measures the strength of the relationship between two variables, and the $p$ and $t$ values, which indicate the level of a significant relationship between two variables (Creswell, 2014; Kothari, 2004). At the 5\% level of significance, the null hypothesis is rejected when $\mathrm{T}_{\text {calculated }}<\mathrm{T}_{\text {table }},=1.97$, or when the $p$-value $<\alpha=.05$ (Creswell, 2014; Kothari, 2004).

The results from the $t$-test showed a positive and significant relationship between the teachers' VBL and the head teachers' VBL $(\beta=.79, t(44)=8.61, p<.05)$ (see Table 11). Based on the results, the null hypothesis was rejected, and the alternative hypothesis $-\mathrm{H}_{\mathrm{A}} 1$ : $\mathrm{A}$ significant relationship between the teachers' VBL and the head teachers' VBL - was accepted. Table 11

The Summary of Regression Model Statistics

\begin{tabular}{ccccc}
\hline Path variables & Path coefficients & $r$ & $p$ & $t$ \\
\hline $\mathrm{X}_{1}$ and $\mathrm{X}_{2}$ & $\beta_{12}=.79$ & .60 & .000 & 8.61 \\
\hline Source. Research Data (Sambu, 2020, p. 130) & & &
\end{tabular}

To understand this relationship, interviews with eight purposely selected participants comprising head teachers and preschool teachers were scheduled. Participants were asked to describe what value-based leadership meant to them using their own words and experiences. The responses to the question asked aided the researchers in understanding the relationship between variables and getting the best answers to the research question as per the pragmatic philosophy. The descriptions assisted in understanding the inconsistencies in the practice of $\mathrm{VBL}$ in vision $\left(r_{s}=.000, p>.001\right)$, and in clear thinking $\left(r_{s}=.35, p>.001\right)$.

\section{Findings from the Interviews}

The data generated from the eight participants were subjected to the Attride-Stirling (2001) five-step process to generate themes using Miner Lite v. 2.0.6. The themes extracted from Miner 
Lite were organized using Word SmartArt, following the Attride-Stirling (2001) web-like thematic network.

The primary themes emerged directly from the research data, but the organizing themes were either direct or indirect, depending on the interpretation given by the researchers. Braun and Clarke (2006, p. 80) say that 'themes emerging' can be misunderstood to mean that they 'reside' in the data, and if we scrutinize keenly, they will 'emerge,' like Venus on the half shell. Braun and Clarke further argue that if themes 'reside' somewhere, they dwell in our minds from our thinking about our data and generating relationships as we draw and interpret their meanings. For the research question "What do you understand by value-based leadership," all the organizing themes 'emerged' from the research data, except 'capacity building,' which emerged from the mind of the researchers (Braun \& Clarke, 2006) (see Figure 4).

Teachers differed in their perspectives of VBL, as illustrated in Figure 4. The themes that came up summarised the meaning of VBL as leading through values and qualities, leadership that one sees, leading by example, helping people grow and adding value to what they do, and doing what one is supposed to do by observing professional ethics.

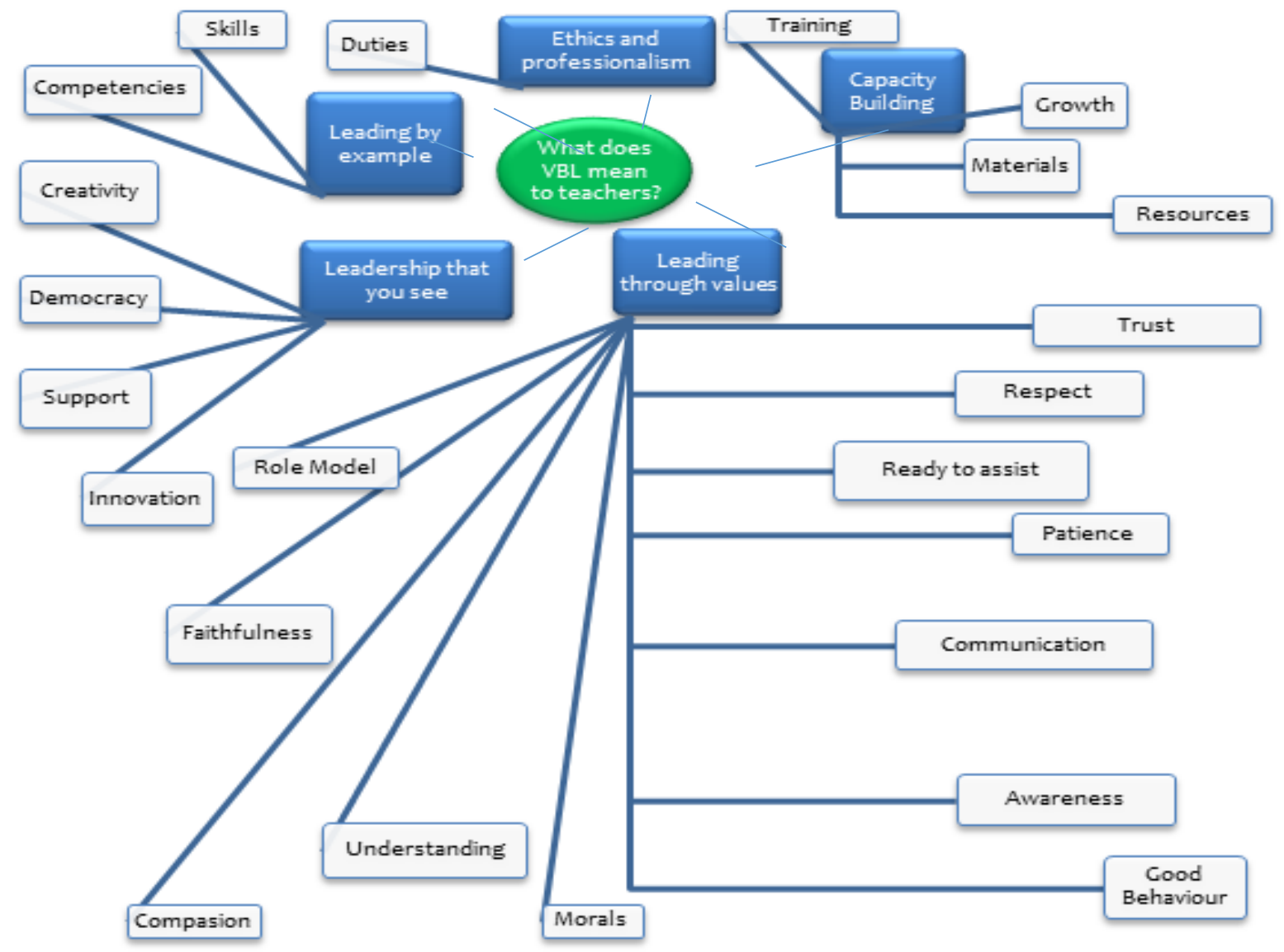

Figure 4. Teachers' perspectives of VBL

Source. Research Data (Sambu, 2020, p.142)

Leading through values was the most popular perspective of VBL and was described by the head teachers. The head teachers narrated these values with ease, possibly because they were practicing them in their workplace or had undergone some training on VBL, and the perspectives were still fresh in their minds. Some of the values communicated include respect, trust, inclusion (understanding and compassion), and integrity (morals and good behavior), 
which resonate well with the indicators of VBL (Garg \& Krishnan, 2003). When leaders possess these values, they do not think twice while acting or making decisions because they guide them to make the right decisions and assume a significant leadership role (Vilma, 2018). In addition, the research on the values of school principals reveals that values serve as their compass and grant meaning to their everyday activities (Abu-Hussain \& Essawi, 2014).

Other studies have demonstrated that values direct people's character as individuals or collectively (as an organization, community, or nation) (Cubukcu, 2014; Turkkahraman, 2014). While positive values, such as friendship, trust, and creativity, help us to socialize with others and make a positive contribution to society (James, 2014), possibly restricting or potentially limiting values, blame, bureaucracy and status-seeking, on the other hand, do just the opposite (Vilma, 2018).

The second perspective of value-based leadership was also by the head teachers as "helping people grow and adding value to what they do', as explained by $\mathrm{HT}_{1}$. The researchers interpreted this to mean 'capacity building.' The purpose of leadership is to enhance other individuals, and the accurate measure of leadership is influence. Therefore, a value-based leader needs to influence the frame of mind or conduct (Reese, 2017). Educational leaders should not lead the organization based upon giving and take principles but instead based on the leader's personality and characteristics and their ability to generate change and serve as an excellent example for those being led (Su-Tuan, 2011). Borrowing from this literature, a value-based head teacher must add value to what teachers do through activities. Leadership qualities must be conveyed by activities, generally in how the activities are led daily, and less in words verbally expressed or composed (Heathfield, 2018) because action speaks louder than words.

Value-based leadership was also perceived as 'leadership that one sees.' The teachers gave this version because they observe what their head teachers do daily. They see how their head teachers make decisions, react to teachers who are not up to standard in performing their duties, and even go out of their way to be creative in managing their leadership roles in the school. For example, one of the participants reported how the headteacher reacted when she used innovation in teaching her physical education lesson.

For example, last week, I came to school wearing tracksuits because they are comfortable as they enable me to take pupils to the playground. I tried involving the parents to buy the same tracksuits for the pupils, but the administration took it negatively $\left(\mathrm{T}_{3}\right)$.

A value-based head teacher should be respectful (when guiding the non-performing teachers) and inclusive (when accommodating the reactive and performing teachers). From a morals and values standpoint, head teachers influence, create and strengthen individuals, team, and school values (Northouse, 2015).

Although value-based leadership was perceived as 'ethics and professionalism,' this perspective can be incorporated in 'capacity building,' which seems to be the overall organizing theme. There was something similar in how T1 presented her perspective of VBL compared with that of $\mathrm{HT}_{1}$ (paired participants for case 1). For $\mathrm{T}_{1}$, the meaning of VBL was described in detail:

Value-based leadership is a lot to do with ethics and professionalism. I think you should come and do what you are supposed to do. The main goal for me is the child; how they are developing at every point, I must master each child. And for me, that is just value- 
based leadership because for you to achieve, it shows if you give your full dedication to what you are actually here for, and not dwell on things which are not necessary for you at that particular point, I think you will have a perfect leadership $\left(\mathrm{T}_{1}\right)$.

On the headteacher's part, VBL meant:

It is twofold. We help the people under us add value to what they are doing by using the correct material. I would also look at it this way, allowing them to grow so that they go through some form of training that will positively impact their children as they learn or impart knowledge. That is how I understand VBL $\left(\mathrm{HT}_{1}\right)$.

This was a single case that depicted consistency in the practice of VBL in the two ranks of teachers. Consistency in the practice of VBL in the two ranks was found earlier, in the quantitative phase, in the indicators of trust, integrity, listening, respect, and inclusion $\left(\mathrm{r}_{\mathrm{s}}>.7\right.$, $p<.001$ ). The narratives in case 1 , as explained above by $\mathrm{T}_{1}$ and $\mathrm{HT}_{1}$, are a confirmation of consistency in the practice of VBL within the two ranks of teachers.

\section{Integrated Findings}

Integration is the explicit combination of quantitative and qualitative findings in mixedmethods research (Creswell \& Plano Clark, 2011). In the explanatory sequential design adopted for this research, interview questions were used to follow up the inquiries that arose from the first phase results (Creswell, 2015). An interview question display (IQD) links the initial quantitative results with the follow-up qualitative findings to explain what was not understood in the initial results (Guetterman, Creswell, \& Kuckartz, 2015). Furthermore, the information presented in the quantitative area depended on the researchers' selection of what data need further explanation (Guetterman et al., 2015). Therefore, this research utilized an IQD matrix to explain the results and findings. The results from the first phase and the findings of the second phase indicated convergence (see Table 12).

The assessment of VBL among head teachers and preschool teachers revealed a general consistency in practice. At the $5 \%$ level of significance the $t$-test results established a positive and significant relationship between teachers' VBL and head teachers' VBL $(\beta=.79, t(47)=$ $8.61, p<.05$.

Table 12

The Relationship of VBL at The Two Ranks of Teachers

\begin{tabular}{|c|c|c|c|c|}
\hline Research Question & \multicolumn{4}{|c|}{ What is the relationship between the VBL of the head teachers and preschool teachers in Kajiado North? } \\
\hline $\begin{array}{l}\text { Associated Survey } \\
\text { Theme }\end{array}$ & Quantitative Data & Qualitative Data Examples & $\begin{array}{l}\text { Associated } \\
\text { Qualitative Code }\end{array}$ & $\begin{array}{l}\text { Data Convergence } \\
\text { label }\end{array}$ \\
\hline $\begin{array}{l}\text { Strong and } \\
\text { consistent practice } \\
\text { of VBL exists } \\
\text { between head } \\
\text { teachers and } \\
\text { teachers in Kajiado } \\
\text { North. }\end{array}$ & $\begin{array}{l}\text { The head teachers' } \\
\text { VBL significantly } \\
\text { predicts teachers' } \\
\text { VBL }(\beta=.79, t(47)= \\
8.61, p<.05 . r=.60\end{array}$ & $\begin{array}{l}\text { Value-based leadership has a lot to do } \\
\text { with ethics and professionalism. I think } \\
\text { you should come and do what you are } \\
\text { supposed to do. }\left(\mathrm{T}_{1}\right) \text {, the same view as } \\
\ldots \text { we help the people under us add } \\
\text { value to what they are doing by using } \\
\text { the correct material ... }\left(\mathrm{HT}_{1}\right)\end{array}$ & Professional ethics & Confirmed \\
\hline
\end{tabular}

\section{Consistent Practice of VBL Across Teachers Ranks and its Implications for Schooling}

The practice of VBL in the two ranks of teachers showed consistency in integrity, respect, listening, trust, and inclusion but revealed inconsistencies in vision and clear thinking. A similar study by Brewster and Railsback (2003) that investigated the characteristics of school heads and school environment showed that, in schools where trust, cooperation, and the quality of the 
relationship between teachers are strong, students feel confident, safe, see their teachers as more caring, and achieve more in terms of learning outcomes. In contrast, in schools where test scores are declining, teachers are bound to say that they do not trust each other (Brewster \& Railsback, 2003).

Further, Youngs (2007, p. 104) explains that "[t]rust develops when school leaders support teachers' work consistently and share responsibility for decisions related to curriculum, hiring, and professional development." This is consistent with what was found in other studies (Goldring \& Rallis, 1993; Louis, Kruse, \& Marks, 1996; Spillane, Halverson, \& Diamond, 2001).

The other significant indicators that portrayed the consistent practice of VBL by both the teachers and head teachers were integrity, listening, respect and inclusion. It is the consistent practice of VBL that makes the school succeed in all spheres. Some researchers have found that a successful head of school is an exceptional, instructive leader in offering support to teachers and adequately realizing leadership procedures. Such a head gives educational help to the teachers. It offers them, professional models, such as showing teachers how to make schemes of work and lesson plans using best practices and motivating them to improve their work (AbuHussain \& Essawi, 2014).

Also, consistency in the practice of VBL, primarily through integrity, trust, and respect, creates an open organizational atmosphere and yields excellent outcomes regarding teacher conduct. It improves teachers' organizational behavior, expands their devotion, and raises their teaching degree (Sergiovanni, 1990). The results are consistent with previous research, in which strong positive relationships between authentic leaders and authentic followers were found to create excellent organizational outcomes (Avolio \& Gardner, 2005; Brown \& Treviño, 2006; Luthans \& Avolio, 2003; May et al., 2003).

In contrast to the consistency in the practice of VBL to integrity, trust, listening, respect, and inclusion, the other two indicators that failed in the consistency test, that is vision $\left(r_{\mathrm{s}}=.000, p\right.$ $>.001)$ and clear thinking $\left(r_{s}=.35, p>.001\right)$. While the head teachers rated the preschool teachers' vision at a very high level of $4.18(S D=.681)$, the preschool teachers rated the head teachers' vision at a lower value of 3.91 $(S D=.44)$. A value-based leader concerning this indicator expects to build a vision and find ways of communicating it to the followers. The low rating by teachers is a clear indication that the head teachers did not communicate the school's vision.

In terms of clear thinking, preschool teachers rated their head teachers at a higher level, of $4.27(S D=.65)$, while the head teachers gave a lower rating to the teachers, of $3.96(S D=.88)$. This means that, from the preschool teachers' perspectives, their leaders had a vision, were clear in their thoughts about their own beliefs, human nature, the role of the school, the measurement of performance, and so on, but failed to communicate the same to the teachers. This finding implies that school leaders should communicate the school's vision transparently and support teachers in implementing it.

\section{Conclusion}

This research examined the relationship between the VBL of head teachers and the VBL of preschool teachers in Kajiado North. The results showed a positive relationship in the practice of VBL across teachers' ranks. There was consistency in the practice of VBL through integrity, 
respect, trust, inclusion, and listening, but inconsistencies were found in vision and clear thinking. Consistency in implementing VLB by teachers is critical in the classroom because it creates a consistent environment in which meaningful learning of values may occur. According to the study, head teachers should be taught VBL qualities, particularly communication skills, in order to help them deliver on their vision and clear thinking. In addition, future studies should be carried out in different locations to validate the results.

\section{References}

Abu-Hussain, J., \& Essawi, M. (2014). Value orientation and leadership style among school principals in Israel's Arab education system. International Journal of Business Administration, 5(3), 49-58.

Adams, P. (2005). Citizenship: How is it different to PSHE and how can it be done? Education, 33(3), 3-13.

Akaranga, S., \& Ongong'a, J. (2013). The phenomenon of examination malpractice: An example of Nairobi and Kenyatta universities. Journal of Education and Practice, 4(18), 87-97.

Ahmad, N., \& Hamid, M. T. S. (2020). Teachers' perceptions regarding the effect of instructional leadership practices of primary school head-teachers on teacher effectiveness. Journal of Research, 14(2), 231-248.

Amadala, B., \& Kaluoch, M. (2015 Oct., 22). SH.1000 and mobile phone are all you need to get a full paper. Daily Nation Newspaper.

Anzene, S. (2014). Trends in examination malpractice in Nigeria educational system and its effects on the social - economic and political development of Nigeria. Asian Journal of Humanities and Social Sciences, 2(3), 1-8.

Attride-Stirling, J. (2001). Thematic networks: An analytic tool for qualitative research. Qualitative Research, 1(3), 385405 .

Avolio, B., \& Gardner, W. (2005). Authentic leadership development: Getting to the root of positive forms of leadership. The Leadership Quarterly, 16(3), 315-338.

Babbie, E. (2004). Laud Humphreys and research ethics. International journal of sociology and social policy, 24(3/4/5), 1219. https://doi.org/10.1108/01443330410790849

Bakken, L., Brown, N., \& Downing, B. (2017). Early childhood education: the long-term benefits. Journal of Research in Childhood Education, 31(2), 255-269. doi.org/10.1080/02568543.2016.1273285

Bandura, A. (1977). Social learning theory. Englewood Cliffs, N.J.: Prentice-Hall, Inc.

Bandura, A. (2018). Toward a psychology of human agency: Pathways and reflections. Perspectives on Psychological Science, 13(2), 130-136. doi:10.1177/1745691617699280

Bogdan, R. C., \& Biklen, S. K. (1982). Qualitative research for education: An introduction to theory and methods. Boston: Allyn and Bacon.

Braun, V., \& Clarke, V. (2006). Using thematic analysis in psychology. Qualitative Research in Psychology, 3(2), 77-101.

Brewster, C., \& Railsback, J. (2003). Building trusting relationships for school improvement: implications for principals and teachers. By request series. Retrieved from https://eric.ed.gov/?id=ED481987

Brown, M., \& Treviño, L. (2006). Ethical leadership: A review and future directions. The Leadership Quarterly, 17(3), 595616.

Bryman, A. (2012). Social research methods (4 ${ }^{\text {th }}$ ed.). New York, NY: Oxford University Press.

Bryman, A., \& Bell, E. (2015). Business research methods. London: Oxford University Press

Busch, T., \& Murdock. A. (2014). Value-based leadership in public professions. London: Palgrave Macmillan.

Campbell, T. (1996). Technology, multimedia, and qualitative research in education. Journal of Research on Computing in Education, 30(9), 122-133.

Cohen, J. (1988). Statistical power analysis for the behavioral sciences ( $2^{\text {nd }}$ ed.). Hillsdale, NJ: Erlbaum

Converse, J. M., \& Presser, S. (1986). Survey questions: Handcrafting the standardized questionnaire (No. 63). Sage. 
Copeland, M. K. (2014). The emerging significance of values-based leadership: A literature review. International Journal of Leadership Studies, 8(2), 105-135.

Creswell, W. J. (2014). Research design: Qualitative, quantitative, and mixed-method approaches (4 ${ }^{\text {th }}$ ed.). Thousand Oaks, CA: Sage.

Creswell, J. W., \& Plano Clark, V. L. (2011). Designing and conducting mixed methods research (2 ${ }^{\text {nd }}$ ed.). Thousand Oaks, CA: SAGE.

Cubukcu, F. (2014). Values education through Literature in English classes. Procedia - Social and Behavioural Sciences, $116,265-269$.

Dean, K. W. (2008). Values-based leadership: How our personal values impact the workplace. The Journal of Values-Based Leadership, 1(1), Article 9. Retrieved from https://scholar.valpo.edu/cgi/viewcontent.cgi?article=1008\&context=jvbl

Gage, N. A., Scott, T., Hirn, R., \& MacSuga-Gage, A. S. (2018). The relationship between teachers' implementation of classroom management practices and student behavior in elementary school. Behavioral Disorders, 43(2), 302-315.

Garg, G., \& Krishnan, V. R. (2003). Transformational leadership and organizational structure: The role of value-based leadership. In S. Bhargava (Ed.), Transformational leadership: Value-based management for Indian organizations (pp. 82-100). New Delhi: Response Books (Sage Publications).

Gold, A., Evans, J., Earley, P., Halpin, D., \& Collarbone, P. (2003). Principled principals? Values-driven leadership: Evidence from ten case studies of "outstanding" school leaders. Retrieved from https://www.open.edu/openlearn/ocw/pluginfile.php/619937/mod_resource/content/1/e859_openlearnunit_chpt10_gold_ et_al.pdf

Goldring, E. B., \& Rallis, S. F. (1993). Principals of dynamic schools: Taking charge of change. Newberry Park, CA: Corwin.

Guetterman, T., Creswell, J. W., \& Kuckartz, U. (2015). Using joint displays and MAXQDA software to represent the results of mixed methods research. In T. Matthew, G. McCrudden, C. Schraw, \& W. Buckendahl (Eds.), Use of visual displays in research and testing: Coding, interpreting, and reporting data (pp. 145-176). London: Information Age Publishing, Inc.

Heathfield, S. (2018). Leadership values and workplace ethics. Retrieved from https://www.thebalancecareers.com/leadership-values-and-workplace-ethics-1918615

Hennink, M., Hutter, I., \& Bailey, A. (2011). Qualitative research methods. Thousand Oaks, CA: SAGE Publications.

Imenda, S. (2014). Is there a conceptual difference between theoretical and conceptual frameworks? Journal of Social Sciences, 38(2), 185-195.

Independent Electoral and Boundaries Commission (IEBC). (2017). Constituency boundaries. Retrieved from http://thekenyan.co.ke/constituency/kajiado-north-

James, P. S. (2014). Aligning and propagating organizational values. Procedia Economics and Finance, 11, 95-109.

Keith, P. (2014). Introduction to social research: Quantitative and qualitative approaches (3rd ed.). Los Angeles: Sage Publications Inc.

Kothari, C. R. (2004). Research methodology: Methods and techniques ( $2^{\text {nd }}$ ed.). New Delhi: New Age International.

Kothari, C., \& Garg, G. (2014). Research methodology: Methods and techniques (3 ${ }^{\text {rd }}$ ed.). New Delhi: New Age International Ltd.

Lincoln, Y. S., \& Guba, E. G. (1985). Naturalistic inquiry. Beverly Hills, CA: Sage.

Liu, P., Li, L., \& Wang, J. (2020). Understanding the relationship between transformational leadership and collective teacher efficacy in Chinese primary schools. International Journal of Leadership in Education, 23(5), 604-617.

Liu, Y., Bellibaş, M. Ş., \& Gümüş, S. (2021). The effect of instructional leadership and distributed leadership on teacher selfefficacy and job satisfaction: Mediating roles of supportive school culture and teacher collaboration. Educational Management Administration and Leadership, 49(3), 430-453.

Louis, K. S., Kruse, S. D., \& Marks H. M. (1996). School-wide professional community: Teachers' work, intellectual quality, and commitment. In F. M. Newmann \& Associates (Eds.), Authentic achievement: Restructuring schools for intellectual quality (pp. 179-203). San Francisco: Jossey-Bass.

Luthans, F., \& Avolio, B. J. (2003). Authentic leadership development. In K. S. Cameron, J. E. Dutton, \& R. E. Quinn (Eds.), Positive organizational scholarship: Foundations of a new discipline (pp. 241-261). San Francisco: Barrett-Koehler,

Mansor, A. N., Sivavikaraman, S., Izham, M., \& Razak, K. A. (2018). Influence of ethical leadership practices on teacher work engagement at high performing secondary schools: A case study. Journal of Advanced Research in Dynamical and Control Systems, 10(12), 1397-1403.

Maverick, J. B. (2018). What assumptions are made when conducting a t-test? Retrieved from https://www.investopedia.com/ask/answers/073115/what-assumptions-are-made-when-conducting-ttest.asp 
May, R., Chan, A., Hodges, T., \& Avolio, B. (2003). Developing the moral component of authentic leadership. Organizational Dynamics, 32, 247-262.

Mitgang, L. (2012). The making of the principal: Five lessons in leadership training. Perspective. New York, USA: The Wallace Foundation.

Munuhe, M. (2016). How top KNEC officials and school heads leak exams [Press release]. Retrieved from https://www.standardmedia.co.ke/article/2000196236/how-top-knec-officials-and-school-heads-leak-exams

Northouse, P. G. (2015). Leadership: Theory and practice. Thousand Oaks, CA: Sage publications.

Nunnally, J. C., \& Bernstein, I. H. (1994). Psychometric theory (3d ed.) New York: McGraw-Hill.

Nyaga, J. (2018). Citizen education in curriculum to boost war against corruption. Retrieved from https://www.nation.co.ke/oped/opinion/Citizen-education-in-curriculum-to-boost-war-against-corruption/4408084883062-135bruhz/index.html

O'Toole, J. (1995). Leading change: Overcoming the ideology of comfort and the tyranny of custom. San Francisco: JosseyBass Publishers.

O'Toole, J. (2008). Notes toward a definition of values-based leadership. The Journal of Values-Based Leadership, 1(10). Retrieved from http://scholar.valpo.edu/jvbl/vol1/iss1/10

Patton, M. Q. (2001). Qualitative evaluation and research methods ( $3^{\text {rd }}$ ed.). Thousand Oaks, CA: Sage.

Patton, M. Q. (2015). Qualitative research and evaluation methods (4th ed.). Thousand Oaks, CA: Sage.

Polit, D. F., \& Hungler, B. P. (2013). Essentials of nursing research: Methods, appraisal, and utilization ( $8^{\text {th }}$ ed.). Philadelphia, PA: Wolters Kluwer/Lippincott Williams and Wilkins.

Punch, K. F. (2014). Introduction to social research: Quantitative and qualitative approaches (3 ${ }^{\text {rd }}$ ed.). London: Sage Publications.

Reese, S. R. (2017). Leadership core values and beliefs are keys to greatness. Center for Management and Organization Effectiveness. Retrieved from https://cmoe.com/blog/great-leaders-have-specific-beliefs-andcore-values

Reilly, A. H., \& Ehlinger, S. (2007). Choosing a values-based leader: An experiential exercise. Journal of management Education, 31(2), 245-262.

Sambu, J. (2020). Value-based leadership and its implications for citizenship education in preschool institutions in Kajiado North, Kenya (Unpublished doctoral dissertation). Pan Africa Christian University, Kenya.

Seale, C. (1999). Quality in qualitative research. Qualitative Inquiry, 5(4), 465-478.

Sergiovanni, T. J. (1990). Adding value to leadership gets extraordinary results. Educational Leadership, 47, $23-27$.

Simon, M. K. (2011). Dissertation and scholarly research. Retrieved from http://dissertationrecipes.com/

Situma, J., \& Wasike, M. (2020). The challenge of examination malpractices in institutions of higher learning in Kenya. International Journal of Academic Research in Business and Social Sciences, 10(9), 699-710.

Smith, E. (2014). Ethical leadership: A South African financial sector perspective. International Journal of Business Management and Economic Research (IJBMER), 5(5), 80-90.

Spillane, J. P., Halverson, R., \& Diamond, J. B. (2001). Investigating school leadership practice: A distributed perspective. Educational Researchers, 30, 23-28.

Stenbacka, C. (2001). Qualitative research requires quality concepts of its own. Management Decision, 39(7), 551-555.

Su-Tuan, L. (2011). Transformational Leadership: Leadership in Education. Educause.edu. According to the abstract, Created by Su-Tuan Lulee (WIDE) on March 13, 2011.

Turkkahraman, M. (2014). Social values and value education. Procedia - Social and Behavioural Sciences, 116, 622-638.

Van Niekerk, M., \& Botha, J. (2017). Value-based leadership approach: A way for principals to revive the value of values in schools. Educational Research and Reviews, 12(3), 133-142. doi:1.5897/ERR2016.3075

Vilma, Ž. (2018). Leadership values and values-based leadership: What is the focus? Applied Research in Health and Social Sciences, 15(1), 43-58.

Wamahiu, S. (2015). Value-Based Education in Kenya: An exploration of meanings and practices. Republic of Kenya. Ministry of Education. Science and Technology. Women Educational Researchers of Kenya. Retrieved from https://scholar.google.com/scholar?cluster=18163100171014629321\&hl=en\&as_sdt=2005\&sciodt=0,5

Youngs, P. (2007). How elementary principals' beliefs and actions influence new teachers' experiences. Educational Administration Quarterly, 43, 101-137.

Yue, S., Pilon, P., \& Cavadias, G. (2002). Power of the Mann-Kendall and Spearman's rho tests for detecting monotonic trends in hydrological series. Journal of Hydrology, 259(1-4), 254-271. 


\section{Acknowledgments}

Not applicable.

\section{Disclosure Statement}

No potential conflict of interest was reported by the authors.

\section{Funding Acknowledgments}

Not applicable.

\section{Open Access}

The International Journal of Organizational Leadership publishes open access articles under the terms of the Creative Commons Attribution (CC BY) License, which permits use, distribution, and reproduction in any medium, provided the original work is properly cited. 